\title{
Grass Straw Mulching To Suppress Emergence and EaRLy GROWTH OF WEEDS ${ }^{1}$
}

\author{
Palhadas de Gramíneas Visando à Supressão da Emergência e do Crescimento Inicial de Plantas \\ Daninhas
}

\author{
OLIVEIRA JR, R.S. ${ }^{2}$, RIOS, F.A. ${ }^{2}$, CONSTANTIN, J. ${ }^{2}$, ISHII-IWAMOTO, E.L. ${ }^{2}$, GEMELLI, A. ${ }^{2}$, and \\ MARTINI, P.E. ${ }^{2}$
}

\begin{abstract}
Sorghum, pearl millet, and Brachiaria ruziziensis have similar characteristics which have led to their use for mulch formation in no-till systems. This study was carried out to evaluate the potential of these three species as straw suppliers to suppress weed emergence. Initial findings led to the conclusion that both pearl millet and Brachiaria ruziziensis have similar or superior potential as weed suppressors, compared to sorghum straw, a species with recognized allelopathic potential. Subsequently, new trials were conducted under greenhouse conditions by sowing weed species in pots, followed by covering of the soil with the straw under evaluation. Independent experiments were conducted for Euphorbia heterophylla and Bidens pilosa. In each experiment, the factors analyzed were type of straw (pearl millet and $B$. ruziziensis), amount of straw (equivalent to 4 and $8 \mathrm{t} \mathrm{ha}^{-1}$ dry mass) and irrigation method (surface and subsurface). Both pearl millet and B. ruziziensis have shown to be species that can be cultivated to produce straw with allelopathic potential. These effects were effective in suppressing the emergence or early growth of E. heterophylla and B. pilosa. There was no difference in the suppression of emergence of these species when the soil cover level was alternated between 4 and $8 \mathrm{t} \mathrm{ha}^{-1}$ dry mass.
\end{abstract}

Keywords: allelopathy, no-till, beggarticks, poinsettia.

RESUMO - Milheto, sorgo e Brachiaria ruziziensis apresentam caracteristicas comuns que têm levado à utilização dessas espécies para a formação de cobertura morta em sistemas de plantio direto. O presente trabalho foi conduzido visando avaliar o potencial dessas palhadas na supressão de plantas daninhas. Em trabalho preliminar, observou-se que as palhadas de milheto e de B. ruziziensis apresentavam potencial semelhante ou superior ao da palhada de sorgo-uma espécie com reconhecido potencial alelopático - na supressão da emergência e do crescimento inicial de algumas espécies de plantas daninhas. Posteriormente, novos ensaios foram conduzidos em casa de vegetação mediante a semeadura da espécie de planta daninha em vasos, seguindo-se a cobertura do solo com a palhada da cobertura em avaliação. Experimentos independentes foram conduzidos para Euphorbia heterophylla e Bidens pilosa. Em cada experimento, os fatores analisados foram os tipos de palha (milheto e B. ruziziensis), as quantidades de palha (equivalentes a $4 e$ 8 tha ${ }^{-1}$ de massa seca) e os métodos de irrigação (superficial e subsuperficial). Tanto o milheto quanto a Brachiaria ruziziensis demonstram apresentar potencial como espécies que podem ser cultivadas visando à produção de palhadas com potencial alelopático. Esses efeitos foram efetivos na supressão da emergência ou do crescimento inicial de $\boldsymbol{E}$. heterophylla e de B. pilosa. Não houve diferença em termos de supressão de emergência dessas espécies quando o nivel de cobertura foi alternado entre 4 e 8 tha ${ }^{-1}$ de massa seca.

Palavras-chave: alelopatia, plantio direto, picão-preto, leiteiro.

Recebido para publicação em 22.9.2013 e aprovado em 23.1.2014.

Universidade Estadual de Maringá, Maringá-PR, Brazil, <rsojunior@uem.br>.

Planta Daninha, Viçosa-MG, v. 32, n. 1, p. 11-17, 2014 


\section{INTRODUCTION}

Sorghum, pearl millet and Brachiaria ruziziensis have similar characteristics which have led to the use of these species for mulching in no-till systems, particularly in both Brazilian savannah areas and northern Paraná, Brazil. Such systems have been developed in a similar way to that of oat and wheat straw in no-till systems, usually adopted in southern Brazil. Due to their rusticity and tolerance to dry winter in cropping systems during the development stage, these grasses are generally grown (isolated or intercropped) in second harvest (safrinha). B. ruziziensis is the most utilized species in association with winter corn (safrinha corn) in a number of areas in the north and west of Paraná, Brazil.

Grass residues promote soil improvement due to their higher lignin content, allowing an increase of carboxylic and humic acids on the subtracts, favoring the structure and stabilization of soil aggregates, thus, making the soil less susceptible to compaction and erosion, in addition to promoting a more efficient and sustainable no-till system (Lanzanova et al., 2007).

The benefits of mulch from these species have been reported in the literature. However, little has been addressed on the allelopathic potential which such species can present on emergence suppression and initial growth of weeds. According to Rivzi \& Rivzi (1992), the use of mulch (crop debris) is a strategy of better allelopathy use in agriculture. Weed management via crop debris (stubble and straw) has been intensified by the possibility of cost reduction in agricultural production, in addition to a growing concern about the negative impact of synthetic chemicals in the environment. Most natural compounds present less environmental persistence and reduced level of threat to human health.

Such allelopathic effects are best known and reposted in the literature particularly for sorghum and pearl millet. Mulching is able to reduce the development of infesting weeds in following crops (Forney \& Foy, 1985; Einhellig \& Rasmussen, 1989). Levels of $1.3 \mathrm{t} \mathrm{ha}^{-1}$ were sufficient to reduce $50 \%$ of Brachiaria plantaginea and Sida rhombifolia infestation after coverage desiccation. In the same study, $4 \mathrm{t} \mathrm{ha}^{-1}$ of either sorghum straw or pearl millet were sufficient to reduce 91, 96 and $59 \%$ of overall population of S. rhombifolia, $B$. plantaginea and $B$. pilosa, respectively. The presence of sorghum aerial part residues is more important for weed suppression than the presence of root residues (Trezzi \& Vidal, 2004). Some hybrids sorghum foliar extracts inhibit soybean radicle growth up to $54 \%$. However, these effects have not been determined with roots and stems extracts, showing that allelopathic effects are more expressive when sorghum leaves are present (Correia et al., 2005). The main sorghum allelopathic effects have been assigned to the sorgoleone presence in these plant tissues (Einhelling \& Souza, 1992).

Brachiaria ruziziensis is an excellent tropical forage crop and emerges as one of the main species which comprises the CropLivestock Integration System in Brazil. Its implementation has aimed both pasture cultivation for animal feeding (Macedo, 2009) and straw supply for no-till systems, thus, ensuring a higher sustainability for productive environments (Torres et al., 2008; Machado et al., 2010).

In the states of Paraná, São Paulo, Goiás, Mato Grosso do Sul and Mato Grosso, the main utilization potential for this forage might be related to its intercropping with winter corn, which can be sown concurrently or subsequently to crop emergence (Jakelatis et al., 2005). Winter corn intercropped with an inter-row of brachiaria represents an important alternative for straw production without significantly reducing grain yield, increasing crop debris input, and thus providing higher profit returns in soybean-corn succession (Ceccon et al., 2010).

Although allelopathic potential in other brachiaria species has already been discussed in relation to both weeds and crops (Fagioli et al., 2000; Souza et al., 2006; Barbosa et al., 2008; Silva \& Firmo, 2008; Holanda et al., 2010), little is known about the potential of B. ruziziensis.

Most studies published so far focusing on crop debris utilization on growth suppression of other species have used aqueous extracts 
obtained from either maceration or straw extraction. However, the viability of straw applied directly on weed seeds placed on the soil surface has been less used. This is due to the difficulty on distinguishing the allelopathic effect from other physical, chemical and biological effects and also to the possible soil retention of substances with allelopathic-like potential.

This study aims at assessing the potential of sorghum, pearl millet and Brachiaria ruziziensis allelopathic on emergence suppression and initial growth of some weed species.

\section{MATERIALS AND METHODS}

\section{Biomass production in field:}

Brachiaria ruziziensis, pearl millet (IPA Bulk 1BF) and sorghum (BR 601) were the forage crops destined to straw production. These three species were sown on November $19^{\text {th }}, 2007$ at Iguatemi Experimental Farm, Maringá, Paraná. The soil was previously submitted to soil decompaction by using a 5-shank chisel plow shortly before soft in-crop harrowing. Grasses were manually sown and incorporated to soil using a harrow. Two months after sowing, before plant blooming started, the aerial part of each species was harvested and subsequently chopped using a grinder (1-7 cm in size). Initially, the materials were dried in the shade for $48 \mathrm{~h}$ and then in a forced ventilation greenhouse $\left(45^{\circ} \mathrm{C}\right)$. Dry mass content for each species was similar $(14 \%, 13.97 \%$ and $16.76 \%$ for sorghum, pearl millet and $B$. ruziziensis, respectively).

\section{Greenhouse trials - experiment I}

Experimental units carried out in the greenhouse comprised plastic pots $\left(3 \mathrm{dm}^{3}\right.$ volume). The soil utilized for this study was collected from Iguatemi Experimental Farm, Maringá, Paraná $\left(\mathrm{pH} \mathrm{H}_{2} \mathrm{O}=4.80 ; 5.41 \mathrm{~g} \mathrm{dm}^{-3} \mathrm{C}\right.$; $86 \%$ sand $1 \%$ silt and $13 \%$ clay, sand texture).

Greenhouse trials were all performed by sowing weed species in the pots and subsequently covering them with the straw under evaluation in this study.
One hundred seeds of either Amaranthus hibridus or Portulaca oleracea were sowed per pot, each species constituting an independent experiment. Treatments were arranged in a completely randomized block design with four replicates and a $3 \times 5$ factorial scheme. Factors were composed by of three types of straw (B. ruziziensis, sorghum and pearl millet) and five mulching levels $\left(0 ; 3 ; 6 ; 9\right.$ and $\left.12 \mathrm{t} \mathrm{ha}^{-1}\right)$.

The experiment was carried out twice, both using a completely randomized block design with four replicates and data comprising the mean of each trial. Data are displayed as means and standard deviation for comparison purposes between treatments.

\section{Greenhouse trials - experiment II}

The second experiment was also carried out in a greenhouse using the same experimental units and soil from that of the previous trial.

In order to extend the observations regarding weed species, the sowing density per pot in this experiment was 20 seeds of either $E$. heterophylla or Bidens pilosa (independent experiments) whose depth ranged from 2 to $3 \mathrm{~cm}$. After weed sowing, soil coverage was performed using straws according to the block design of each treatment, simulating a no-till system practice environment.

In order to eliminate the chemical effect from the physical effect exerted by the straw, two irrigation methods were used. The first method consisted of superficially irrigating the pots, simulating a precipitation situation. The second consisted of sub-superficially supplying water to the experimental units, so that there was no water flow through the straw, thus, moistening the soil by capillarity.

The treatments were arranged in a completely randomized block design with six replicates and a $(2 \times 2 \times 2)+2$ factorial scheme. Factors evaluated were: two types of straw (pearl millet and B. ruziziensis), two straw amounts (equivalent to 4 to $8 \mathrm{t} \mathrm{ha}^{-1}$ dry mass) and two irrigation methods (superficial and sub-superficial). Two additional control treatments were used, one of them with no straw, using superficial irrigation (Superficial Control) and the other with no straw and using 
sub-superficial irrigation (Sub-superficial Control). For superficial irrigation, water was individually supplied to pots every two days, whereas for sub-superficial irrigation, pots were kept in recipients, which, according to the demand, were filled with enough water to provide soil moistening to the surface.

At 32 days after sowing (DAS), assessments on emerged plants were performed and weed dry mass was also measured at the last evaluation (data not shown). Data were submitted to variance analysis at 5\% probability.

The experiment was carried out twice, using both a completely randomized block design with four replicates and data comprising the mean of either trials. Data are displayed as means and standard deviation for comparison purposes between treatments.

\section{RESULTS AND DISCUSSION}

\section{Effect on emergence and initial growth of Amaranthus viridis and Portulaca oleracea:}

When comparing mulching absence ( $0 \mathrm{t} \mathrm{ha}^{-1}$ ) with low mulching levels ( 3 and $6 \mathrm{t} \mathrm{ha}^{-1}$ ), there is a small increase in density of $A$. viridis (Figure $1 \mathrm{~A}$ ) and $P$. oleracea (Figure 1B) plants emerged for the three mulching species assessed.

As highest levels of mulching are utilized, there is a clear reduction in emerged plant densities. Generally, this effect is most pronounced for $B$. ruziziensis straw (Figure 1A and 1B). The increment on densities of weed plants emerged under low mulching levels using straw may be associated with a higher contact degree between seeds and the soil provided by either the straw or the maintenance of a higher moisture level on the surface of the pots. As straw level increased, both the physical effect of emergence suppression and the possible chemical effects arising from allelochemicals released by straw may have contributed to emergence reduction.

It is interesting to note though that, after emergence, the development of the aerial part of $A$. viridis is only reduced when seedlings grow with the presence of $12 \mathrm{t} \mathrm{ha}^{-1}$ sorghum and
B. ruziziensis straws. On the other hand, under lower mulching levels ( 3 a $9 \mathrm{t} \mathrm{ha}^{-1}$ ), particularly of pearl millet and sorghum, there is an increment on the growth of this weed's aerial part, indicating that straw may have stimulatory and inhibitory effects (Figure 2A). For $P$. oleracea, only reducing effects on the accumulation of aerial part dry mass were observed, mainly for $6 \mathrm{t} \mathrm{ha}^{-1}$ pearl millet and sorghum and for $3 \mathrm{tha}^{-1}$ of $B$. ruziziensis (Figure 2B). This suggests that the magnitude of effects varies according to weed species.

Other chemical, physical and biological effects associated to possible allelopathic effects are also determinant on germination suppression and weed development in a no-till system. Among the most important physical effects are the reduced passage of solar radiation and temperature range on soil superficial layer (Aase \& Tanaka, 1991; Teasdale \& Mohler, 1993). Besides allelopathic interaction, chemical/biological effects of
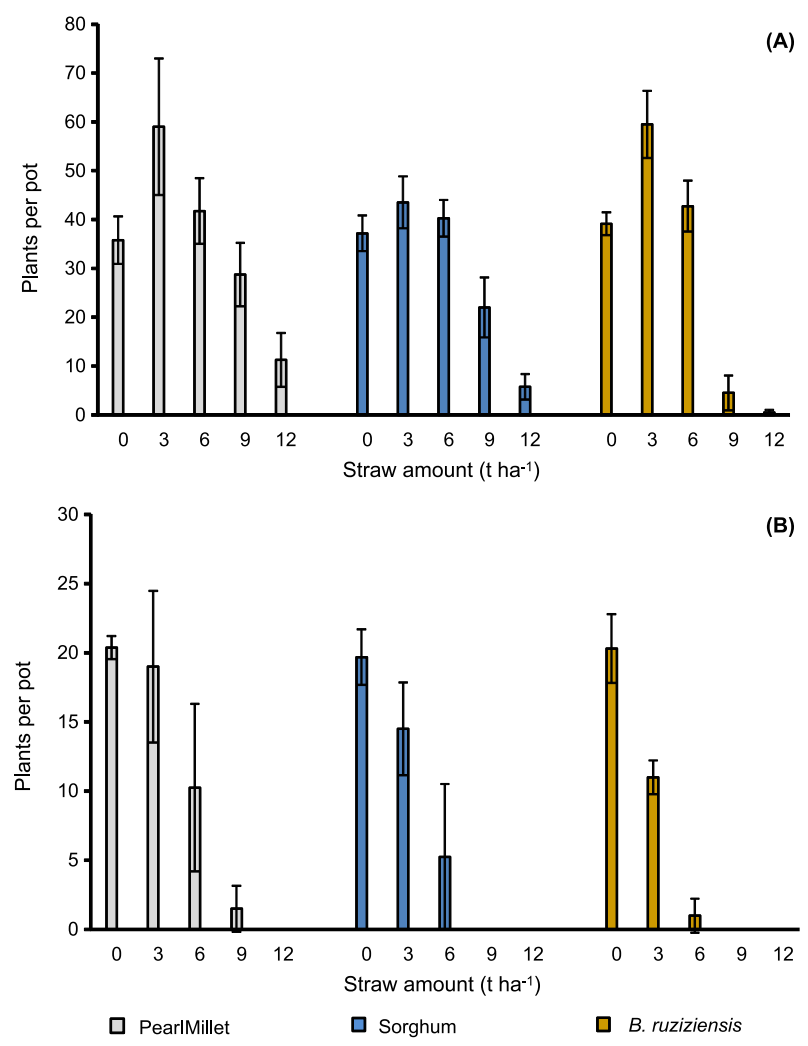

Figure 1 - Density of $A$. viridis (A) emerged plants and P. oleracea (B) at 24 DAS according to the type and amount of straw used as soil coverage. 

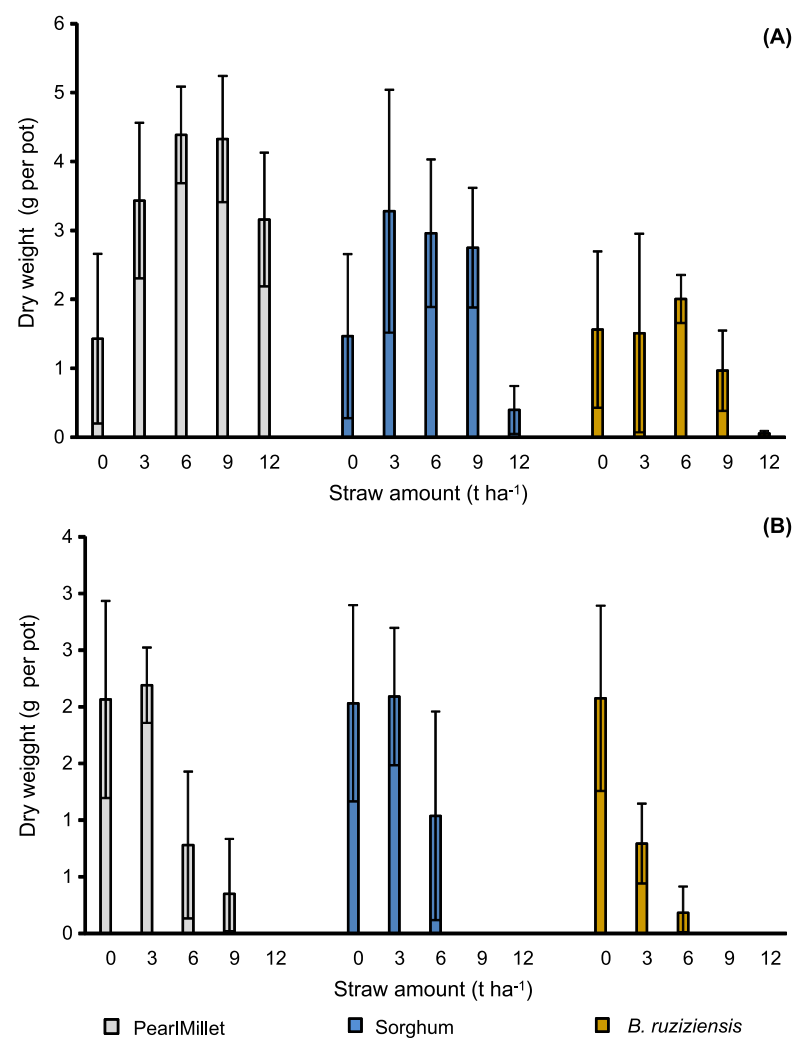

Figure 2 - Dry mass of A. viridis (A) and P. oleracea (B) aerial parts at 24 DAS according to the type and amount of straw used as soil coverage.

mulching include changes in $\mathrm{pH}$ and nutrients dynamics in the soil (Da Ros \& Aita, 1996; Argenta et al., 1999). A number of studies has indicated that, as straw level on soil surface increases, the magnitude of effects also becomes high, resulting in a progressive reduction of weed infestation (Inderjit \& Dakshini, 1995). Because of the multiple effects involved, it is difficult to isolate allelopathy from weed suppression by mulching.

Although straw effects have been similar when compared to the initial flux of weed emergence, distinct behavior for both weed species have been observed on the biomass of the aerial part. For $A$. viridis, an increment in the straw level has shown neither significant (sorghum and B. ruziziensis) nor positive (pearl millet) effects on weed development. On the other hand, for $P$. oleracea, the plants biomass was inversely correlated with the straw amount covering the pots, with emphasis on B. ruziziensis $\geq 6 \mathrm{t} \mathrm{ha}^{-1}$ straw. This might indicate a differential sensitivity of species in relation to straw effects or a possible initial recovering effect. Another possibility would be the small size of seeds, which could result in a reduced straw-imposed limitation responsiveness.

\section{Effect on emergence and initial growth of Europhorbia heterophylla and Bidens pilosa}

By evaluating $E$. heterophylla plant densities (Figure 3A) and B. pilosa (Figure 3B) per pot, it was observed that there was a significant emergence reduction in the presence of straw for both pearl millet and $B$. ruziziensis. However, such effect was only observed when the irrigation of pots was performed by superficial water supply, i.e., when water percolated through the straw deposited on the soil surface. When the irrigation method was sub-superficial, i.e., when water was supplied by capillarity without passing through the straw layers on the pot surface, no inhibition effect on pearl millet or B. ruziziensis was observed, regardless of the straw level used. The aerial part dry mass of these plants (data not shown) presented the same pattern of emergence data in relation to straw.

For pearl millet, mulching produced by the aerial part can reduce weed incidence in a number of intercropping systems. However, it is known that the addition of plant material of pearl millet provides compound release, which negatively interferes on corn, soybean and drybean biomass acumulation (Faria, 2009). According to Narwal et al. (1998), when pearl millet was grown as a forage species, monocotyledon weeds infestation was reduced between 79 and $91 \%$; and dicotyledons infestation was reduced between 84 to $100 \%$. Among all species evaluated according to weed suppression potential (pearl millet, corn, guar, caupi beans and sorghum), pearl millet was the one showing greatest weed emergence suppression in relation to the pearl millet genotype utilized.

Information on the B.ruziziensis allelopathic potential has so far been limited. Preliminary results (Kern-Cardoso et al., 2011; Iwamoto et al., 2011) have shown that $B$. ruziziensis leaves can release phytotoxic 

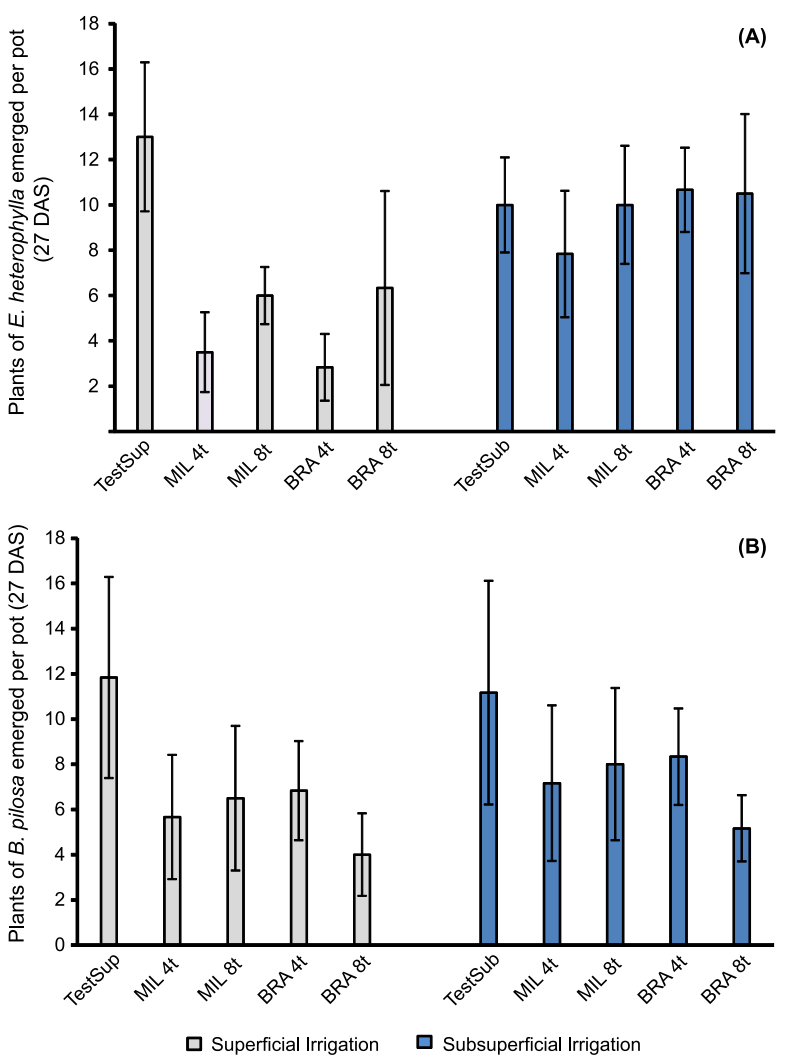

Figure 3 - Plants density of E. heterophylla (A) and B. pilosa (B) emerged at 32 DAS according to irrigation method, type of straw $(\mathrm{MIL}=$ pearl millet; $\mathrm{BRA}=B$. ruziziensis $)$ and straw amount $\left(4 \mathrm{t}=4 \mathrm{t} \mathrm{ha}^{-1} ; 8 \mathrm{t}=8 \mathrm{tha}^{-1}\right)$.

compounds for Euphorbia heterophylla, Ipomoea triloba and Bidens pilosa. High levels of triterpenoid saponins and aconitic acid were found, respectively, in buthanolic and aqueous fractions of the extracts utilized. Changes on the activity of oxidative enzymes such as peroxidase, catalase, ascorbate peroxidase and superoxide dismutase in Euphorbia heterophylla tap roots were observed. It was suggested that, due to substances detected and effects observed in these plants, performance of compounds from $B$. ruziziensis straw might occur in an energy metabolism level and in the oxidative stress induction process.

Therefore, it was observed that both pearl millet and $B$. ruziziensis show potential as soil cover crops with allelopathic potential aiming at weed suppression. Nevertheless, the use of such results in the field should be preceded by researching possible effects of this soil cover crop on the cultivated species. Recent results have also indicated that there is still scope that the effects of $B$. ruziziensis straw may also affect intercropping crops. Researches conducted by Nepomuceno et al. (2010) in order to evaluate agronomic performance of transgenic soybean crop, cv M-SOY 7908 RR, sown in two areas (the first one using Brachiaria ruziziensis straw and the other on fallow agricultural lands using spontaneous plants). Thus, it was conclude that brachiaria desiccation followed by soybean sowing in the same day reduced not only grain yield $(27 \%)$ but also the number of pods per plant $(22 \%)$ when compared to other treatments.

In conclusion, both pearl millet and Brachiaria ruziziensis present potential as species which can be grown seeking straw production with allelopathic potential. Such results were effective on either emergence suppression or initial growth of weed species for both Euphorbia heterophylla and Bidens pilosa. Inhibition effects were more intense when irrigation water was supplied so as to percolate the straws on the soil surface when compared to sub-superficial water supply. Furthermore, there was no difference in terms of emergence suppression for these species when mulching level increased from 4 to $8 \mathrm{tha}^{-1}$ of dry mass. Such findings suggest that the inhibitory effects observed might be of a more chemical than physical nature.

\section{LITERATURE CITED}

AASE, J. K.; TANAKA, D. L. Reflectances from four wheat residue cover densities as influenced by three soil backgrounds. Allelopathy J., v. 83, n. 3, p. 753-757, 1991.

ARGENTA, G. et al. Manejo do nitrogênio no milho em semeadura direta em sucessão a espécies de cobertura de solo e em dois locais. II - Efeito sobre o rendimento de grãos. Ci. Rural, v. 29, n. 4, p. 587-593, 1999.

BARBOSA, E. G.; PIVELLO, V. R.; MEIRELLES, S. T. Allelopathic evidence in Brachiaria decumbens and its potential to invade the Brazilian Cerrados. Braz. Arch. Biol. Technol., v. 51, n. 4, p. 825-831, 2008.

CECCON, G. et al. Uso de herbicidas no consórcio de milho safrinha com Brachiaria ruziziensis. Planta Daninha, v. 28, n. 2, p. 359-364, 2010.

CORREIA, N. M.; CENTURION, M. A. P. C.; ALVES, P. L. C. A. Influência de extratos aquosos de sorgo sobre a germinação e desenvolvimento de plântulas de soja.

Ci. Rural, v. 35, n. 3, p. 498-503, 2005. 
DA ROS, A. O.; AITA, C. Efeito de espécies de inverno na cobertura do solo e fornceimento de nitrogêncio ao milho em plantio direto. R. Bras. Ci. Solo, v. 20, n. 1, p. 135-140, 1996.

EINHELLIG, F. A.; RASMUSSEN, J. A. Prior cropping with grain sorghum inhibits weeds. J. Chem. Ecol., v. 15, n. 3, p. 951-960, 1989.

EINHELLIG, F. A.; SOUZA, I. F. Allelopathic activity of sorgoleone. J. Chem. Ecol., v. 18, n. 1, p. 1-11, 1992.

FAGIOLI, M. et al. Efeito inibitório da Brachiaria decumbens STAPF. PRAIN. e B. brizantha (HOCHST ex A. RICH.) STAPF. cv. marandu sobre a germinação e vigor de sementes de guandu (Cajanus cajan (L.) MILLSP.). B. Ind. An., v. 57, n. 2, p. 129-137, 2000.

FARIA, T. M. Efeitos alelopáticos do sorgo, milheto e soja, como cobertura vegetal, sobre a emergência, micorrização, atividade microbiana e crescimento inicial de milho, soja e feijão. 2009. 103 f. Dissertação (Mestrado em Agronomia) - Universidade Estadual Paulista, São PauloSP, 2009.

FORNEY, D. R.; FOY, C. L. Phytotoxicity of products from rhizospheres of a sorghum sudangrass hybrid (Sorghum bicolor x Sorghum sudanense). Weed Sci., v. 33, n. 5, p. 597-604, 1985.

HOLANDA, F. S. R. et al. Crescimento inicial de espécies florestais na recomposição da mata ciliar em taludes submetidos à técnica da bioengenharia de solos. Ci. Flor., v. 20, n. 1, p. 157-166, 2010.

INDERJIT, DAKSHINI, K. M. M. On laboratory bioassays in allelopathy. Bot. Rev., v. 61, n. 1, p. 29-44, 1995.

IWAMOTO, E. L. I. et al. Potential allelopathic effects of Ruzi grass (Brachiaria ruziziensis) leaf and steam tissues on weed species. In: WEED SCIENCE SOCIETY OF AMERICA ANNUAL MEETING, 51., 2011, Portland. Abstracts... Portland: Weed Science Society of America, 2011. v. 1.

JAKELAITIS, A. et al. Efeitos de herbicidas no consórcio de milho com Brachiaria brizantha. Planta Daninha, v. 23, n. 1, p. 69-78, 2005.

KERN-CARDOSO, K. A. et al. Allelopathic activity of the butanolic fraction and of saponins obtained from residues of ruzi grass (Brachiaria ruziziensis) on th weed species poinsettia (Euphorbia heterophylla L.). In: $6^{\text {th }}$ World Congress on Allelopathy, 2011, Guangzhou. Annals... Guangzhou: International Allelopathy Society, 2011. v. 1.
LANZANOVA, M. E. et al. Atributos físicos do solo em sistema de integração lavoura-pecuária sob plantio direto. R. Bras. Ci. Solo, v. 31, n. 5, p. 1131-1140, 2007.

MACEDO, M. C. M. Integração lavoura e pecuária: o estado da arte e inovações tecnológicas. R. Bras. Zootecnia, v. 38, p. 133-146, 2009. (Número Especial)

MACHADO, L. A. Z.; ASSIS, P. G. G. Produção de palha e forragem por espécies anuais e perenes em sucessão à soja. Pesq. Agropec. Bras., v. 45, n. 4, p. 415-422, 2010.

NARWAL, S. S.; SARMAH, M. K.; TAMAK, J. C.; Allelopathic strategies for weed management in the rice-wheat rotation in northwestern India. In: OLOFSDOTTER, M.

(Ed.). Allelopathy in rice. Manila, Philippines: International Rice Research Institute, 1998. p. 117-131.

NEPOMUCENO, M. P. et al. Efeito dos períodos de dessecação de cobertura vegetal antecedendo a semeadura da soja. In: CONGRESSO BRASILEIRO DA CIÊNCIA DAS PLANTAS DANINHAS, 27., Ribeirão Preto, 2010. Resumos... Ribeirão Preto: SBCPD, 2010. p. 2250-2253.

RIZVI, S. J. H.; RIZVI, V. Exploitation of allelochemicals in amproving crop productivity. In: RIZVI, S. J. H.; RIZVI, V. (Ed.). Allelopathy: basic and applied aspects. London: Chapman and Hall, 1992. p. 443-472.

SILVA, A. C.; FIRMO, D. Efeitos alelopáticos causados pelo capim braquiarão (Brachiaria brizantha) no desenvolvimento inicial da palmeira de babaçu (Orbignya spp.). R. Verde, v. 3, n. 4, p. 1-7, 2008.

SOUZA, L. S. et al. Efeito alelopático de capim-braquiária (Brachiaria decumbens) sobre o crescimento inicial de sete espécies de plantas cultivadas. Planta Daninha, v. 24, n. 4, p. 657-668, 2006.

TEASDALE, J. R.; MOHLER, C. L. Light transmittance, soil temperature, and soil moisture under residue of hairy vetch and rye. Agron. J., v. 85, n. 3, p. 673-680, 1993.

TORRES, J. L. R.; PEREIRA, M. G.; FABIAN, A. J. Produção de fitomassa por plantas de cobertura e mineralização de seus resíduos em plantio direto. Pesq. Agropec. Bras., v. 43, n. 3, p. 421-428, 2008.

TREZZI, M. M.; VIDAL, R. A. Potencial de utilização de cobertura vegetal de sorgo e milheto na supressão de plantas daninhas em condição de campo: II - Efeitos da cobertura morta. Planta Daninha, v. 22, n. 1, p. 1-10, 2004. 